\title{
THE ISRAELI-PALESTINIAN SEPARATION WALL AND THE ASSEMBLAGE THEORY: THE CASE OF THE WEEKLY ROSARY AT THE ICON OF OUR LADY OF THE WALL
}

\author{
ELISA FARINACCI \\ Independent researcher \\ University of Bologna \\ Piazza San Giovanni in Monte, 2 \\ 40124, Bologna, Italy \\ e-mail: elisa.farinacci2@unibo.it
}

\begin{abstract}
In this work I analyse the ethnographic case study of the icon of Our Lady of the Wall as establishing a unique ritual landscape among the cement slabs of the Israeli-Palestinian Wall separating Jerusalem from Bethlehem. Although the Wall has been widely described as a technology of occupation on one side and as a device to ensure security on the other, through Latour's concept of assemblages I unearth its agency in developing a Christian shrine. Through a decade of weekly recitations of the Rosary along the Wall near Checkpoint 300, the Elizabethan nuns of the Caritas Baby Hospital have been invoking Mary's help to dismantle the Wall. This weekly ritual represents both political dissent against the bordering action enacted by the Wall, as well as giving visibility to the plea of the Palestinian Christian right to live in this territory in the face of their status as an ethnoreligious minority.

KEYWORDS: Israel-Palestine $\bullet$ Our Lady of the Wall • assemblages $\bullet$ bordering $\bullet$ Elizabethan nuns of the Caritas Baby Hospital • shrine • ritual
\end{abstract}

\section{N T RODUCTION}

Our understanding of globalisation today must recon with its inherent exhibition of a tension between opening and barricading (Brown 2010: 7-8). While it is generally recognised that this term has predominantly referred to the pervasive development of transnational connections, people's movement across national boundary lines and a growing range of media reaching across borders (Hannerz 1996: 4), today we are witnessing an increasing erection of walls around the globe. Prominent examples include the wall built between Mexico and the United States; the Morocco Wall of Western Sahara, which separates the Moroccan-controlled Southern Provinces from the Polisario-controlled areas known as the Saharwi Arab Democratic Republic; between India and Bangladesh; between North and South Korea; between Uzbekistan and Kyrgyzstan; between Saudi Arabia and Yemen; between Zimbabwe and Botswana; between Afghanistan and Pakistan; between Kuwait and Iraq; the wall that in Belfast divides the Protestant and 
Catholic neighbourhoods; the wall in Cyprus that divides the Turkish from the Greek area; the wall built in the Italian city of Padua in Via Anelli to separate the immigrant and poor neighbourhoods from the rest of the citizens (Brown 2010: 8; Farinacci and Filippini 2015), or even the very recent barricading along the borders of several European nations against the massive arrival of migrants.

In this work I address the Wall running between Israel and Palestine, ${ }^{1}$ particularly the segment that separates South Jerusalem from the Palestinian municipalities of Bethlehem and Beit Jala. According to the 2012 survey conducted by the United Nations Office for the Coordination of Humanitarian Affairs (OCHA), 542 obstacles hinder the movement of the Palestinians in the West Bank area (OCHA 2012). Among these many diverse barriers, the $\mathrm{Wall}^{2}$ perhaps represents one of the greatest physical obstacles between Israel and Palestine. Its construction began in 2002, and it is planned to extend for approximately 773 kilometres at completion. Approximately $90 \%$ of the barrier's length consists of an "electronic fence flanked by paved pathways, barbed-wire fences, and trenches" (B'Tselem 2011). However, the 15-kilometer-long segment of the Wall that is the focus of my research is an eight-meter-high concrete barrier. My investigation aims at examining the impact that the physical presence of the Wall has on the Palestinian Christian population residing in the Bethlehem governorate. In this article, I will address the peculiar aspect of the development of a ritual landscape among the cement slabs near checkpoint 300, where the Christian population protests against the bordering agency of the Wall through the weekly recitation of the Rosary while reaffirming its right to dwell on the land as a religious minority.

Although numerous connoisseurs and scholars of the Israeli-Palestinian issue, such as political scientist Wendy Brown (2010: 29), address the Wall in terms of "a technique of strategic land appropriation that poses as an antiterrorist technology" or "as an offensive political military technology, posing as a pacification structure", in my research I have unveiled a more complex dimension to the Wall's impact on the Palestinian Christian population through an innovative framework connecting new materialism with phenomenology. The approach is based on Bruno Latour's concept of assemblages. Latour's notion of assemblages allows for a democratic interplay between the humans, who usually dominate the attention of scholars, and the frequently overlooked material things, in an attempt to bridge the divide between subject and object. As he assures his readers,

it is not a matter of replacing a gamut of actions traditionally associated with the subject by a shorter range of actions that would reduce the first. On the contrary, the associations that are presented [...] seek to add to the first list a longer list of candidates (Latour 2004: 75),

thus also allowing non-humans to become the focus of scholarly analysis. Therefore, in this article I adopt and adapt the theoretical framework of Latour's concept of assemblages in as much as it allows to challenge the notion that agency pertains solely to human actors while embracing the idea that things also exert power. Accordingly, the Wall is not just an inert cement structure that the Israeli Government constructed in order to guarantee the safety of its people, but it exercises an agency distributed across a gamut of human and non-human actants. In particular, in my research I have addressed five dimensions in which the Wall, understood as an assemblage, exercises its agency: 
Palestinian land appropriation, control and surveillance of the lives and movement of the Palestinians in general and of the Christians in particular, community and family fragmentation and separation, acts of sumud or steadfastness developed by the Christians, and the topic of this article, the development of a Christian ritual landscape among its cement slabs. Herein, I examine how the Wall assemblage, in addition to gathering actants of surveillance and control also encompasses an entanglement of religious practices, rituals, and materials that are developing into a novel Christian shrine. In this work, I analyse how the physical presence of the Wall, and the agency that it deploys, exhorted the Italian congregation of Elizabethan nuns who run the Caritas Baby Hospital, to initiate a weekly recitation of the Rosary near the militarised entrance to and from Bethlehem known as Checkpoint 300. This ritual was developed over a decade ago in order to beseech the Virgin Mary for the miracle of destroying the Wall. The continuity of the recitation of this prayer along the route of the Wall, has gradually developed into a unique ritual landscape where human and non-human actants interact and interconnect with the Wall. A few of the involved actants that were identified include: guns, soldiers, watchtowers, gates, barbed wire, army vehicles, eight-meter-high cement slabs, interaction with religious bodies, Holy Masses, the Eucharist, Rosary beads, a new prayer written especially to be recited at the Our Lady of the Wall icon, the Emmanuel's convent isolated by the Wall, nuns, activists, foreign pilgrims, and Hail Maries. Hence, herein, following in the footsteps of Robert Alvarez (1995), Gloria Anzaldúa 2012 [1987], Latour (1999; 2004; 2005), Jane Bennett (2005; 2010), Kristy Nabhan-Warren (2010), Sonia Hazard (2013), Alejandro Lugo (2015), Valentina Napolitano et al. (2015), Nurit Stadler (2015), Nurit Stadler and Nimrod Luz (2015), I document how considering the Wall as an assemblage allows the notion that the Wall is merely a technology to ensure safety or exercising occupation to be challenged, while unearthing the development of a new Christian ritual landscape along a segment of its route in opposition to its presence.

\section{GEO-POLITICALCONTEXT}

As a result of the Oslo peace process initiated in the 1990s, and particularly due to Oslo II, known as the Interim Agreement on the West Bank and Gaza Strip, the West Bank was subdivided into three areas of jurisdiction: Area A where the Palestinian Authority (PA) possesses full civil and security control, Area B in which the PA retains civil control with a joint Israeli-Palestinian security control, and Area $C$ which is under full Israeli civil and security control. In particular, in the Bethlehem Governorate, which includes the municipality of Beit Jala, approximately 6,000 people dwell in 17 residential areas located in Area C, thus directly under Israeli control.

More than $85 \%$ of Bethlehem governorate ${ }^{3}$ is designated as Area C, the vast majority of which is off limits for Palestinian development, including almost 38\% declared as "firing zones", 34\% designated as "nature reserves", and nearly $12 \%$ allocated for settlement development (OCHA 2015).

Thus, the Oslo II agreement essentially gave Israel military control of the "interstices of an archipelago of about two hundred separate zones of Palestinian restricted autonomy of the West Bank" (Weizman 2007: 11). 
The separation between Israel and Palestine became more rigid and overt through the construction of the renowned "security fence" also known as the Wall. Consequent to Ariel Sharon's walk on Temple Mount/Haram al-Sharif on September 28, 2000, the Al-Aqsa Intifada (also known as the second Intifada) exploded causing approximately 6,371 victims among Palestinians and 1,083 among Israelis (B'Tselem 2010). Thus the period between the years 2000 and 2005 witnessed numerous suicide bombings and terrorist attacks against the Israeli civilian population, which propelled the development of the security barrier project. The barrier's total length has been planned to run for approximately 773 kilometres along the 1949 armistice line (while in fact the total length measures twice the length of the Green Line) and its construction initiated in the year 2002 with the consent and under the supervision of Prime Minister Ariel Sharon. Specifically, the Wall in the Bethlehem Governorate

extends across 53.5 kilometers starting at the eastern rural area north of Al-Khas village and runs south to reach Um Al-Qassies village; it then extends towards the west, bypasses the southern part of Abu Ghniem mountain north of Beit Sahour, before it continues northwest of Bethlehem and Beit Jala cities and westward to run along bypass road \#60 south of Al-Khader village, it then runs southeast towards Wad Al-Nis to encompass Efrat settlement (ARIJ 2007: 25).

Moreover, the route of the Wall extends south and southwest isolating the western rural area of the Governorate along the Gush Etzion settlement Bloc (ibid.).

While strongly acknowledging and affirming the shared experience of the impact of the physical presence of the Wall both by Muslims and the diverse Christian denominations living in this territory, this research focuses on the Christian Catholic segment of the Palestinian inhabitants (about 8,000 people belonging to 1,000 families). According to the 2014 CIA census, Christians represent 1.0 to 2.5 percent of the population in the West Bank (The World Factbook), and about "three-fourths of all Bethlehem Christians live abroad" (Adelman and Kuperman 2001: 1). In contrast, there is a higher percentage of Christians in Israel, constituting approximately $2 \%$ of the population (according to the Israel Central Bureau of Statistics, on Christmas Eve 2011 Christians numbered 154,500). The reason for selecting the Christian community as the focus of my research lies in the fact that their status as a minority, even in an historically predominantly Christian city like Bethlehem, unearths peculiar dimensions of the Wall's agency that would not have arisen otherwise, such as the development of the weekly ritual of the prayer of the Rosary near Checkpoint 300 addressed in this work. In fact, given their status as a double minority in Israel (compared to the Jewish and Muslim population) and as a minority compared to the Muslims in the West Bank, as Stadler and Luz (2015) highlight, the development of the shrine of Our Lady of the Wall does not uniquely reveal their dissent against the presence of the Wall, but it also reinforces their right as an ethno-religious minority to reside on the land.

\section{METHODOLOGY}

As stated above, the present research work focuses on the effects of the Wall on the Christian population living in the municipalities of Bethlehem and Beit Jala. The data 
was collected through extensive fieldwork conducted over three expeditions for a total of twelve months. I planned the first two trips in two different moments of the year in order to capture both the impact of the Wall on ordinary life, as well as during the particularly meaningful and solemn festivity of Easter's Holy Week. The decision to focus my research on the segment of the Wall in the Bethlehem Governorate area allowed me to investigate multiple dimensions of the Wall's agency. Several cases analysed in my work, in fact, took place along this 15-kilometer-long segment of the Wall ${ }^{4}$ (in places already constructed and in others still under construction). Furthermore, this peculiar section of the Wall enabled the exploration of its temporal dimension. Since the Wall is still under construction, I was able to gain an insight into the perceptions and attitudes of the people who witnessed the erection of the first cement blocks in 2002, of those who are currently living in the vicinities of the Wall and are thus forced to interact with its presence daily, as well as of those who have been informed of its intended route, which will sever their homes from their fields.

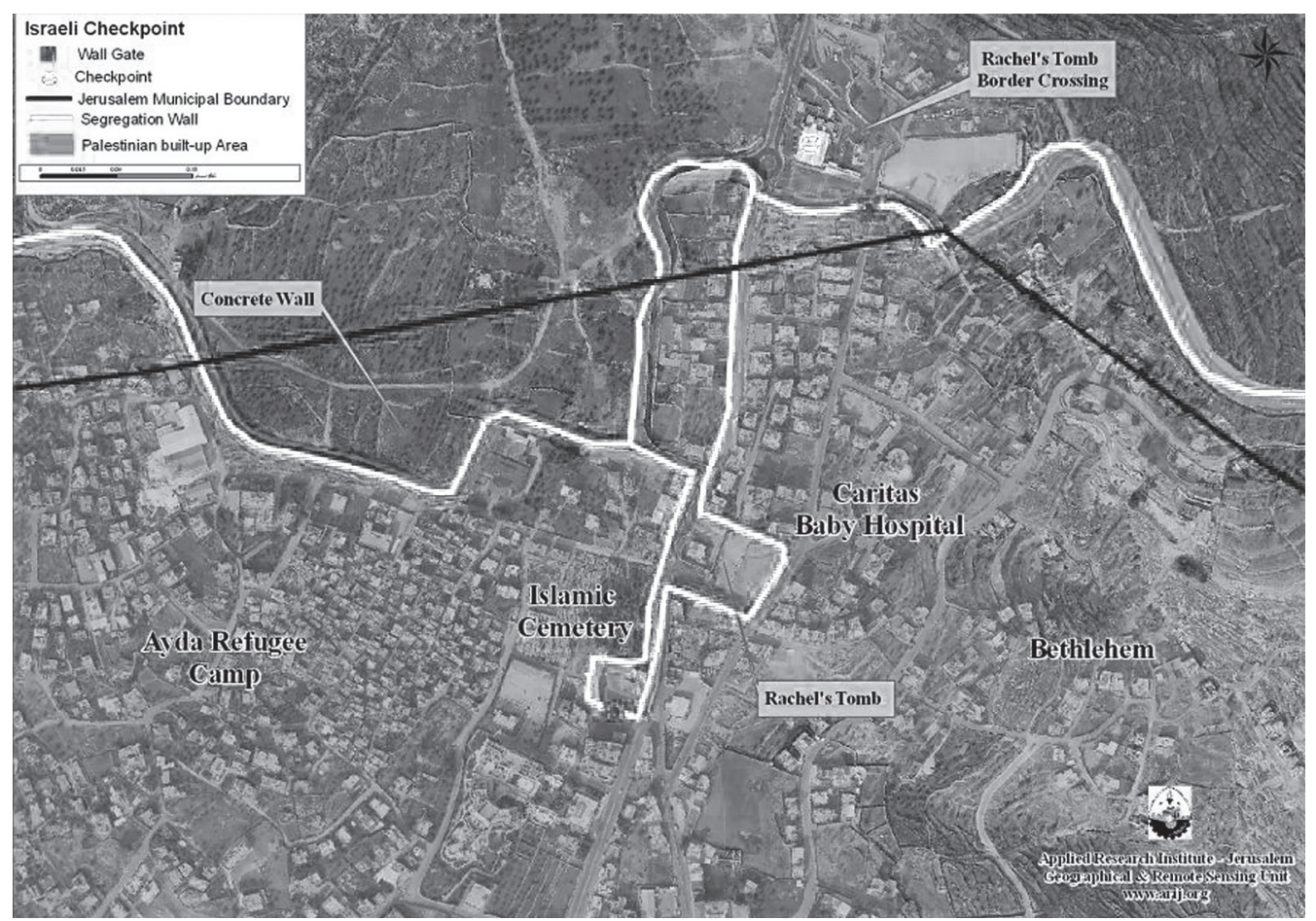

Figure 1. Map of the Rachel's Tomb Area and Checkpoint 300 (ARIJ).

The methodology I employed to collect the data consisted of a combination of interviews and participant observation. The interviews, when possible, were conducted in a structured manner. However, given the sensitivity of the issue and the possible repercussions on the local population if found criticising Israeli policies, I collected most of the data in an informal manner, in ways that protected the identity of my interlocutors. The subjects of interest in the research were lay Christians ${ }^{5}$ residing in the area, local authorities such as the Mayors of Bethlehem, lawyers, and local clergy. I also gathered 
data by observant participation during the celebration of the Holy Masses, other community events on important Christian Holidays such as Advent and Easter, and all the activities involving the Christmas Youth Choir of the Saint Catherine Parish.

Furthermore, I adopted a particular technique when conducting the interviews, which proved to be extremely successful due to the unconventional nature of my approach: the respondents had to describe their experience of the Wall with just one word. This method forced the interviewees to think about the Wall in an unfamiliar way. As a Christian woman told me, this question represented a challenge for the Arabs who tend to be very descriptive. Thus, when asked, they had to either condense different elements of the assemblage called Wall, or select its paramount element. Furthermore, in order to gain insights on their embodied experiences of being in a world surrounded by the Wall, I asked them to narrate their memories of the times when the Wall was being constructed, of how their lives changed since its erection, and of a particular event that they will never forget in connection to the presence of the Wall.

Let us now observe how carrying out the research through the adoption of this particular methodology revealed the necessity to adopt Latour's concept of assemblages in the analysis of the impact of the Wall on the local Christian population.

\section{THE WALL AS A NON-HUMAN ACTANT}

The decision to adopt the assemblage framework arose from the complexity of the data collected through the interviews conducted during the fieldwork. Let us look at a concrete example derived from my conversation with Mariam, one of the women involved in the development of the Sumud Story House project. ${ }^{6}$ First of all, Mariam works in the Rachel Tomb Area (See Figure 1), a zone of the city of Bethlehem where the Wall, in order to annex the tomb of the Jewish matriarch Rachel to the Israeli national territory, winds in between the homes of the Palestinians who live there. Due to the pervasive presence of the Wall, this particular area has progressively emptied of its inhabitants, becoming desolate. The Sumud Story House was opened there in order to revitalise this part of town. Furthermore, this area hosts Checkpoint 300. The construction of this checkpoint interrupts Hebron Road, which represented the major artery connecting Jerusalem to Bethlehem. This sophisticated passage point regulates the entrance and exit to and from Bethlehem on foot through a series of queues, turnstiles, and metal detectors, and - for vehicles - a route through the solid iron gate that Mariam mentions in the interview. These are Mariam's words describing her experience of the Wall:

I looked at the gate, it was closed, I felt that someone is really trying to kill me; someone is trying to put his hands on my neck [she tightens her hands around her neck mimicking someone strangling her] [...] I will never ever forget this feeling. Imagine yourself, the main entrance is closed and you don't have the authority to open it so this is what I felt at that moment, that someone is killing me [...]. Killing, illness, serpent, a lot of ugly words, these words even cannot describe what we feel when I say it is killing me, it's not just a word, it is really killing me. So you know looking at the Wall, it's ten metres high and when you look at it you can't even continue to look at it, you feel really afraid, just sometimes I feel really afraid. 
This description provides a few insights onto the importance of incorporating a new materialist interpretative framework through Latour's concept of assemblages. Instead of describing the Wall through adjectives such as 'ugly', 'tall', 'solid', she depicts it as strangling her, that is, she attributes to the Wall an action, that of choking. Already, in this first observation the materiality of the Wall, that is, its physical presence, does not appear inanimate, but she describes it as possessing the same agentic power as a human subject. Secondly, if we acknowledge that the Wall has agency, what does it mean that it strangles someone? After all, the Wall might have been anthropomorphised, but it still does not have actual hands. So what is it about the Wall that strangles?

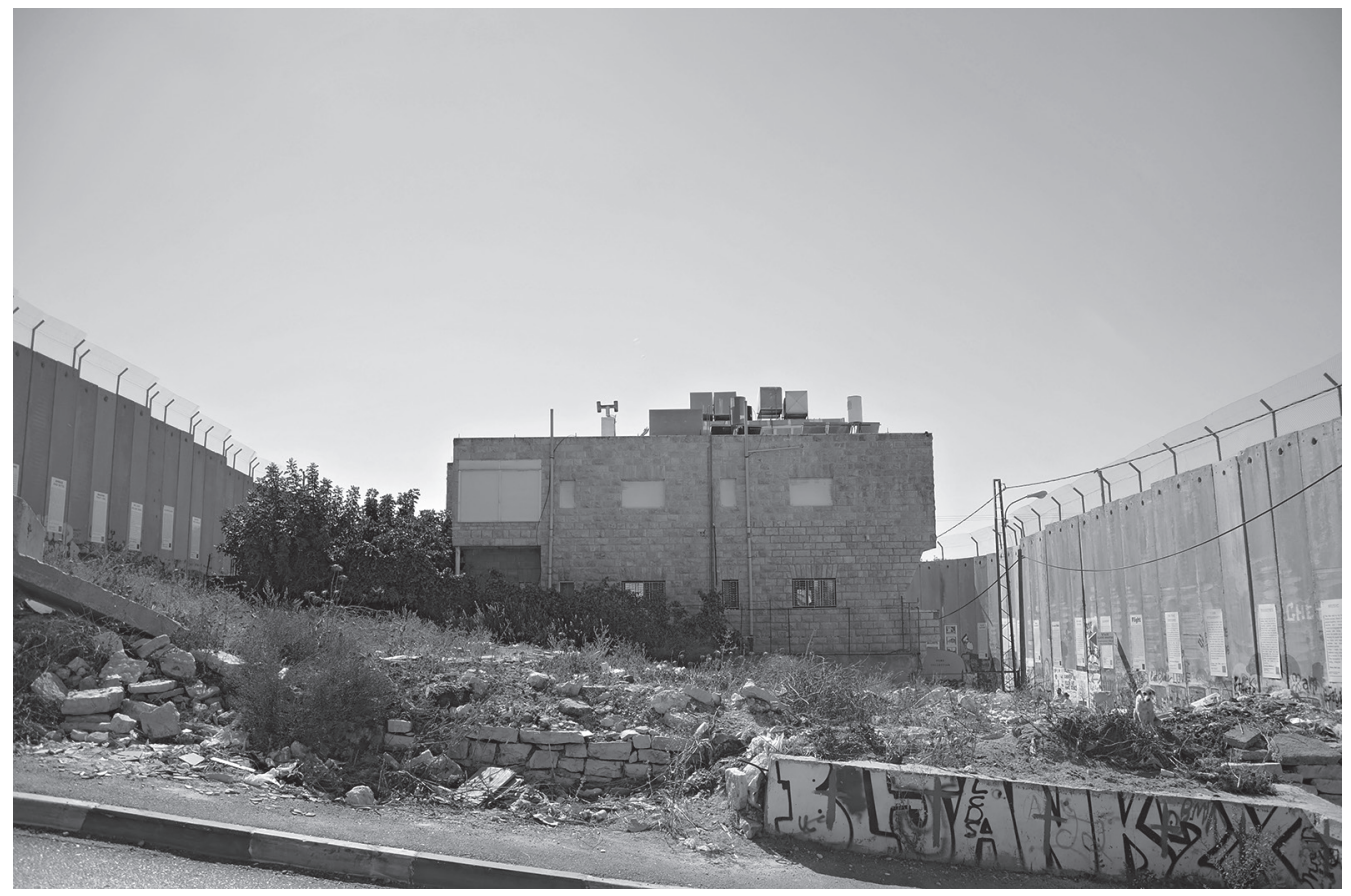

Photo 1. Home of the Anastas family surrounded on three sides by the Wall. Photo by the author.

In order to answer these questions, we must understand that we are facing a group of different elements, an assemblage of parts that, because of their material presence, structure, design, architecture, and humans operating with and through them provoke the sensation of choking. Mariam's description of the Wall as a "serpent", and as "killing" can be understood as alluding to the snake's ability to wrap its body around the prey choking them with its coils, thus killing them by taking their breath away. Furthermore, the Wall's 'serpentine' quality may come from its non-linear architecture and route, which insinuates itself deep within the city wrapping its 'body' around buildings severing them from the city's major arteries and from Jerusalem, thus preventing Palestinian inhabitants from accessing the Israeli city. This is the case with the Anastas family whose home, due to its proximity to Rachel's Tomb, is surrounded on three sides by the Wall isolating them from the rest of the city (see Photo 1). Furthermore, my 
request to narrate an unforgettable experience relating to the Wall reveals the necessity to analyse the Wall in terms of an assemblage of different actants. In this particular case, Mariam describes her experience of standing in front of the closed checkpoint's gate impeding the movement to and from Bethlehem. The fact that she chose such an event made me realise that she considered the checkpoint and its gate as integral parts of the Wall. Moreover, this particular experience ties to Mariam's previous description of the strangling agency of the Wall, which can be explained as a result of the Israeli Army's unilateral authority to deny access to the city through the checkpoint's gate.

This short example allows us to recognise that the Wall is neither a listless monolithic object, nor a simple set of cement slabs. Through Mariam's narration we understand that the Wall possesses agency and that it is composed of a gamut of different elements whose agencies interact within the assemblage Wall. Thus, I was able to comprehend the responses of my interlocutors who, when asked about the Wall, did not merely address its cement slabs, but spoke about their lost land, their vegetables, checkpoints, icons, etc. They clearly understood that the Wall has a complex presence that gathers a multiplicity of elements. Latour thus delivers us a world where "agency is always a complex agency, unlocalizable and distributed across assemblages of both humans and things" (Hazard 2013: 66). Thus, it becomes apparent that the adoption of a framework such as that of Latour's assemblages becomes indispensable when analysing the elements emerged from the field, more so than other theories committed to the study of materials. Often, as Sonia Hazard (2013) reminds us, theories such as social constructivism, despite their attention to materials, do not centre their scholarly enquiry on objects specifically, but de-objectify objects in order to "gain better insights into their makers' ontology" (Hurd 2008: 98), thus maintaining an anthropocentric perspective that is firmly rejected by scholars of the materialist turn.

Accordingly, when examining the data collected, I could not find myself in complete agreement with Latour when he asserts (2005: 78-79) that

we have to take non-humans into account only as long as they are rendered commensurable with social ties [...]. To be accounted for, objects have to enter into accounts. If no trace is produced, they offer no information to the observer and will have no visible effect on other agents. They remain silent and are no longer actors: they remain, literally, unaccountable.

My findings show this idea not to be completely accurate. In fact, there is clear evidence that the Wall acts despite its entrance into the Christian's accountability. ${ }^{7}$ Given these premises, I needed to integrate the concept of assemblages with the standpoint of those scholars who work within a new materialist perspective (Barad 2007; Coole and Frost 2010; Bryant 2011; Bogost 2012; Dolphijn and van der Tuin 2012; Barrett and Bolt 2013; Connolly 2013; Hazard 2013; Morton 2013) in order to account for the narrations recorded in the field. The common denominator among new materialists relies on the belief that

material things possess a remarkable range of capacities that exceed the purview of human sense or knowing, and, therefore [...] that the materiality of material things themselves must be carefully considered, not merely interpreted for their implications on human concerns (Hazard 2013: 64). 
Certainly, the attention to the agency of non-humans that the new materialist perspective guarantees and defends allows us to gain an innovative outlook onto the impact of the Wall's physical presence. However, I find this unilateral focus on objects troublesome, given the fact that my understanding of the agency of the Wall came almost exclusively from the human experience and perception of the human interlocutors. This aspect represents, in my opinion, a paradox to the investigation of non-human agency; how can the materialist framework coexist with what seemed a cultural phenomenological method of collecting data? I believe that Jane Bennett's work Vibrant Matter: A Political Ecology of Things (2010), speaks eloquently about the issue at hand. She recounts her encounter with an assemblage of materials on the street (a glove, a rat, pollen, a bottle cap, and a stick) and how their materiality "started to shimmer and spark" due to the "contingent tableau that they formed with each other, with the street, with the weather that morning, with me" (Bennett 2010: 5). As she explains, had the sun not glistened on the glove she might not have been able to notice the dead rat and so on. Because they were all there and positioned in that particular way, she was able to catch "a glimpse of an energetic vitality inside each of these things, things that [...] [she] generally conceived as inert" (ibid.). In the assemblage that Bennett describes, these non-humans appeared "as vivid entities not entirely reducible to the contexts in which (human) subjects set them, never entirely exhausted by their semiotics" (ibid.). This assemblage of materials formed a "contingent tableau" with each other and with her, her mood that day and the specific weather; she became an active participant in that particular assemblage. Furthermore, it seems that she also shares our concern for the inevitability of factoring humans into the equation when enquiring about the agency of non-humans:

Was the thing-power of the debris I encountered but a function of the subjective and intersubjective connotations, memories, and affects that had accumulated around my ideas of these items? Was the real agent of my temporary immobilization on the street that day humanity, that is, the cultural meaning of "rat," "plastic," and "wood" in conjunction with my own idiosyncratic biography? It could be. But what if the swarming activity inside my head was itself an instance of the vital materiality that also constituted the trash? (Ibid.: 10)

This eloquent query does not simply address the methodology through which to investigate the agency of non-humans, it uncovers the challenging issue concerning the relationship between phenomenology (Heidegger 1962; Merleau-Ponty 1962; 1968; Csordas 1990; 1994a; 1994b; 1999; 2011) and materialism. Through Bennett's work we reveal the challenge faced by anthropologists whose "first task [...] is to convey [...] feelings empathetically" (Miller 2011: 41). As Bennett asserted, she was the one to perceive this vibrancy and thus phenomenology cannot be eliminated from the "assemblage". She was the one that day who, because of her mood and assertiveness, because of her beingin-the-world, perceived the tableau of objects in the street.

Specifically, this article analyses how the adoption and adaptation of Latour's assemblage framework allowed me to unearth the development of a peculiar ritual landscape in response to and as a part of the Wall assemblage. In the next section, I will discuss how the more overt elements connected to security near Checkpoint 300 where the prayer of Rosary is recited weekly - that is, cement slabs, watchtowers, barbed wire, gates for cars, checkpoints, cameras, lighting fixtures, metal detectors, turnstile entrances, finger 
printing, soldiers who check IDs - interconnect with the dimension of the Christian practice of the Rosary recitation. As a result, among the above-cited human and nonhuman actants, we discover also the presence of praying nuns, pilgrims, rosary beads, the Our Lady of the Wall icon, Hail Maries, Salve Regina, and prayers to achieve the miracle of making the Wall fall. Consequently, the Wall understood and constructed in order to guarantee security to the Israeli inhabitants and experienced as a technology of occupation by the Palestinians, when understood as an assemblage reveals the development of a ritual landscape that is both part of its assemblage and at the same time developed in opposition to its presence.

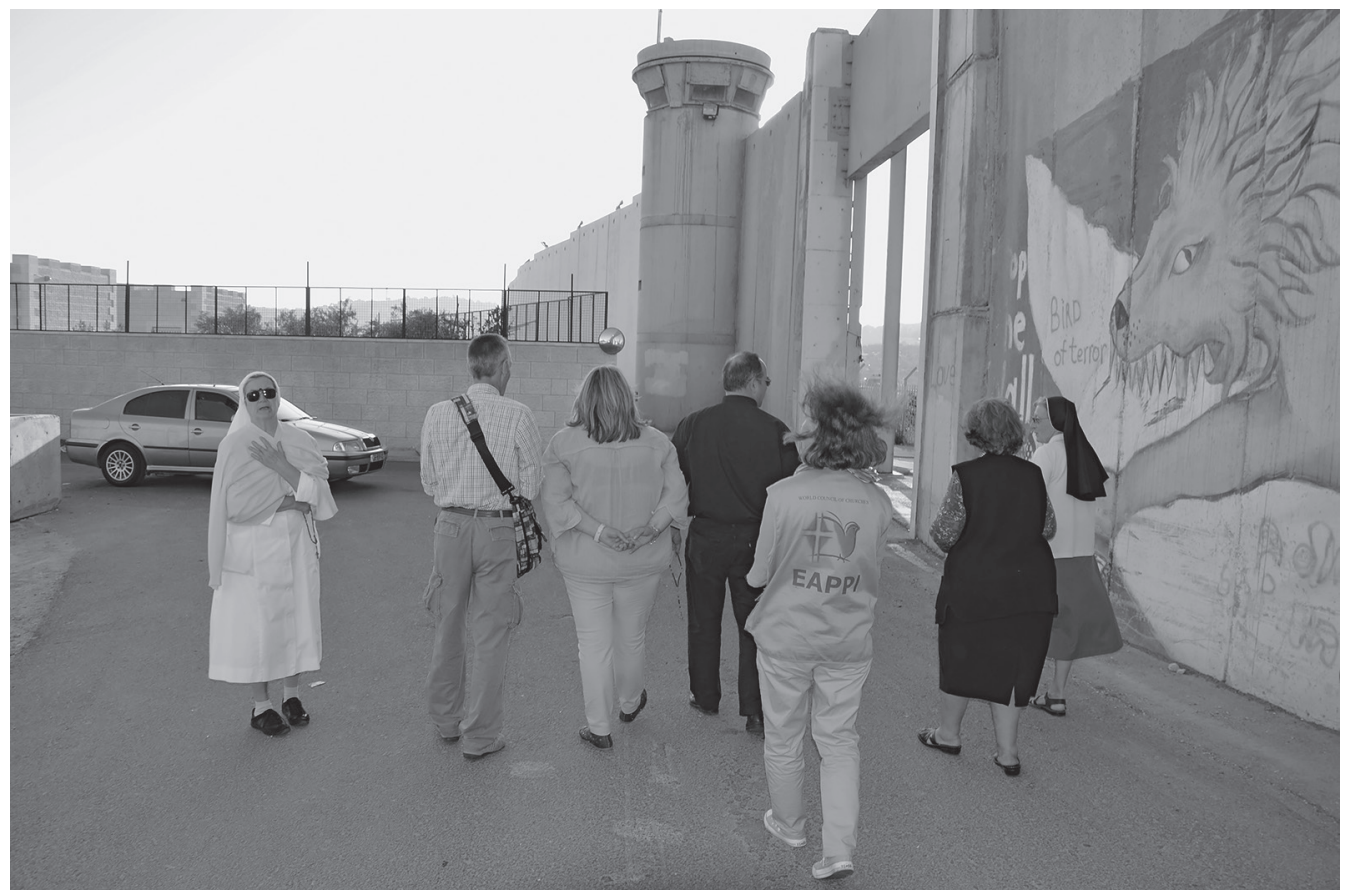

Photo 2. The Elizabethan nuns, Abuna M., an EAPPI volunteer, and Christians recite the Rosary by the Wall next to the entrance of Checkpoint 300. The Checkpoint's watchtower looms over it. Photo by the author.

THE WEEKLY PRAYER OF THE ROSARY: AN ETHNOGRAPHIC ACCOUNT

As I approached the edges of Bethlehem, the smell of car exhaust became more intense. I met Sister Anne at the Caritas Baby Hospital, the only paediatric facility in the West Bank established in the 1952 by a Swiss priest Father Ernest. She offered to accompany me toward the checkpoint where they recite the Rosary every Friday afternoon. As we strode on the narrow sidewalk we had to pay attention not to bump into the wing mirrors of the numerous cars lined up waiting to exit Jerusalem through Checkpoint 300. 
This checkpoint is just one among the "61 permanently staffed checkpoints (excluding checkpoints on the Green Line), 25 partial checkpoints (staffed on an ad-hoc basis) and 436 unstaffed physical obstacles, including roadblocks, earth mounds, earth walls, road gates, road barriers, and trenches" (OCHA 2012) present in Palestine. Right in front of the gate leading to Israel, stood two soldiers controlling the permits of the drivers and opening the trunks of the cars. As they saw us approaching on foot they became alerted, but as soon as Sister Anne showed them her rosary they relaxed and went back to their duties. Under these circumstances, every Friday at 17:30 in the winter and at 18:00 in the summer, the Italian Elizabethan nuns of the Caritas Baby Hospital gather near the vehicular entrance to and from Bethlehem. As I previously mentioned, this passage point consists of a gate that can close when the Israeli military feels threatened, a watchtower with military presence at all times, surveillance cameras, and bright flood lights. The recitation of the Rosary begins at this location, in plain view both of the Israeli soldiers and of the many Palestinian drivers who wait in line to exit from the checkpoint (see Photo 2). Depending on whether the soldiers are newly assigned to guard the checkpoint or already familiar with this weekly appointment, the arrival of the faithful and pilgrims may be more or less smooth. If the soldiers are not yet aware of this initiative, the nuns reassure them by 'unsheathing' their rosaries and explaining that they are going to pray. My usage of the term unsheathing is not unintentional since Sister Anne tells the pilgrims that "there are those who throw stones and those who throw rosary beads". This statement truly reveals the significance of focusing the inquiry on materiality. The beads of the rosary not only assist the Christians during prayer by materialising each Hail Mary, but they also become a laissez-passer upon approaching the checkpoint, as well as becoming the weapon that these Christian Catholic nuns have chosen to fight the presence of the Wall.

The moment of prayer is structured as follows: one person throughout the recitation remembers the Mysteries, while the other participants take turns in different languages reciting half of the Hail Mary while the rest, each one in his or her own language, declaims the second half. As the fingers work their way through the beads of the wooden rosaries, the group walks back and forth from the checkpoint to the end of the road in front of the gates of the Greek Catholic convent of the Emmanuel where the recitation ends with the singing of the Salve Regina in Latin in front of the Our Lady of the Wall icon (See Photo 3).

The participants are regularly few in number and are rarely local Palestinians. In fact, as Sister Anne discloses "last week it was just the two of us [Sister Anne and Abuna Mario] praying together at the Wall, but we prayed anyway because it is by now a fixed appointment that we care about". ${ }^{8}$ The reason behind this absence is closely connected to the policies governing permits to enter Israel:

Ten years ago, there was a stricter security especially concerning the inhabitants, thus they were afraid that the soldiers might recognise them. [...] Thus there was not, and still there is not, a strong Palestinian presence exactly because there is this fear of coming close to the checkpoint and being recognised especially since there is always a soldier in the watchtower who closely controls who goes there. (Sister Anne) 


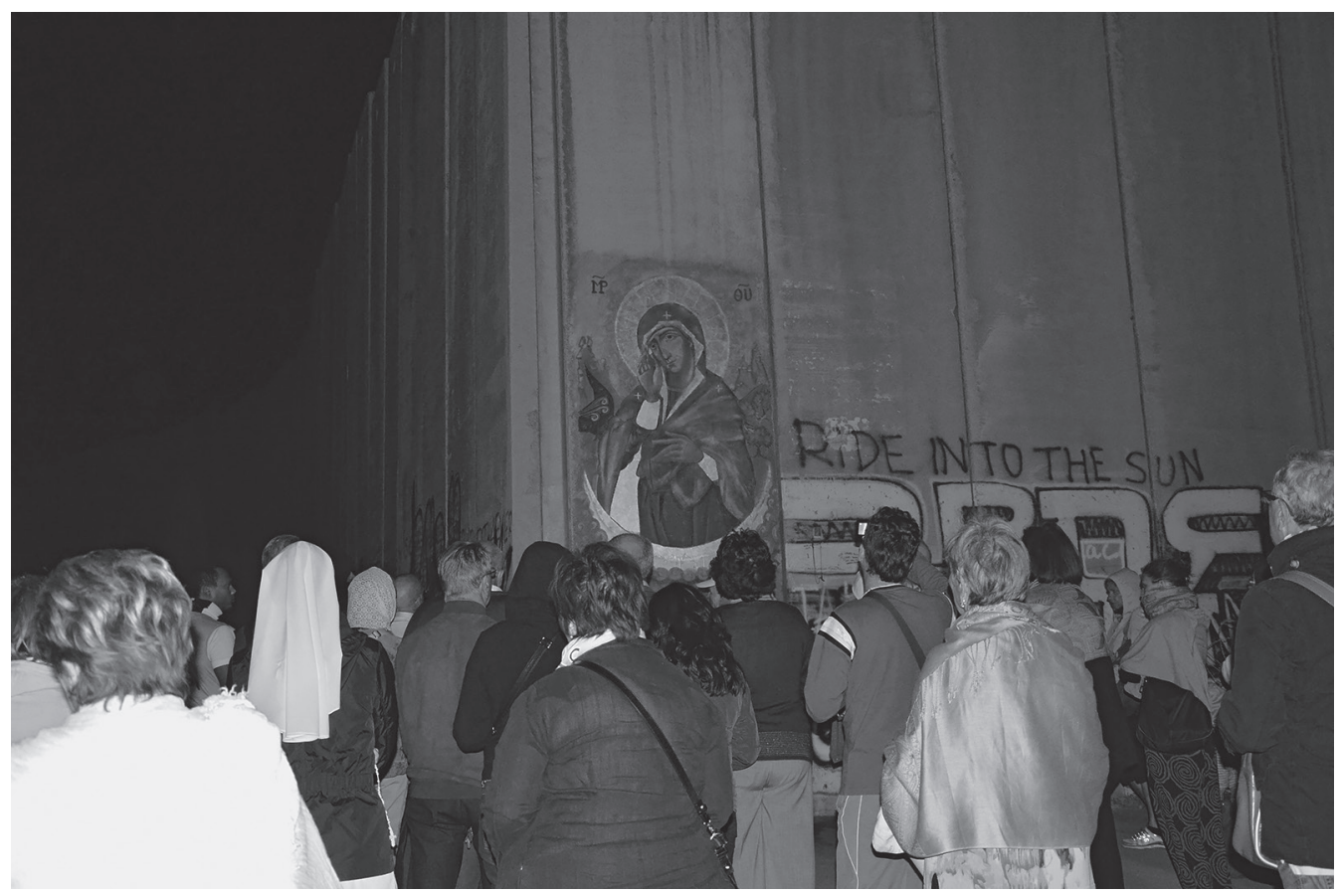

Photo 3. Pilgrims conclude the recitation of the Rosary through the singing of the Salve Regina in Latin while standing in front of the Our Lady of the Wall Icon. Photo by the author.

The lack of a strong Palestinian presence is linked to the fact that any type of participation in activities suspected to be connected to political protests or uprisings often leads to the future denial of a permit to enter the State of Israel. Already the Christians benefit from the infrequent permits allotted almost exclusively in conjunction with major religious festivities and any suspicion of political dissent may jeopardise allocation, preventing them from visiting family and friends living on the other side of the Wall.

The initiative of the weekly Rosary commenced in 2004 when a priest visited the Caritas Baby Hospital, a facility that is overseen by the Elizabethan nuns. In that year, the first cement slabs were placed without anyone truly understanding the meaning and magnitude of this barrier:

We yet did not understand what this barrier meant because its dimensions were unknown; we could guess the route because they were digging the gutters especially here. There were clues even if they were not very clear; you could understand that it was enclosing something. (Sister Anne)

Thus this priest prompted them with this question "And you? What will you do to face the construction of the Wall?" (Sister Anne). As the priest left, the nuns began to brood on this question.

Why not find something to show that we oppose this thing? But something that will not provoke, something that will not make the Israelis and the soldiers retaliate; something that will become a moment of meditation both for us and for them 
and that will draw us in the spiritual dimension and in that of prayer. [...] Then if we believe in prayer we may ask the Lord to decide what to do. Thus we chose to recite the Rosary. (Sister Anne)

This is how the Elizabethan nuns devised the idea to organise a moment of prayer at the segment of the Wall near the entrance to and from Bethlehem under the suspicious supervision of the Israeli soldiers who gave them

quite a few problems meaning that they did not want to let us go, so they used to come with their vehicles and would drive back and forth following us with their machineguns pointed at us as if to say "the next time you will not come here". (Sister Anne)

In addition to my presence, the weekly Rosary gathered a few international nuns from different countries around the world, always at least one Elizabethan nun, a couple of EAPPI (Ecumenical Accompaniment Programme in Palestine and Israel) volunteers, sometimes some seminar students and Franciscan monks, many Italian pilgrims, and almost always Clemens, a middle-aged Palestinian woman whose house has been severed from the family land by the Wall. Clemens is one of the few local Christians (Greek Catholic) who participate in the Rosary. Clemens joined the weekly Rosary due to particular events in her life that were closely connected to the construction of the Wall.

Basically, when they started building the Wall, she owned all the land on the other side of the Wall that was part of her olive garden and they [Israeli soldiers] without asking anything expropriated her land and uprooted the olive trees. Her husband a year and a half later, after they built the Wall, gave a piece of his land, the piece where the paved road passes in order to allow the nuns [of the Emmanuel convent] to enter, otherwise they would not have had an access [to their property]. (Sister Anne)

Thus Clemens' husband donated a strip of their own land in order to pave the path that connects the entryway to and from Bethlehem to the Emmanuel's convent which, after the construction of the Wall, was severed from the main road and access to the city. The same pathway is now used for the prayer of the Rosary. However, a few years after the construction of the Wall Clemens' husband, who had lost most of his possessions, died of a heart attack; "he could not stand looking every morning at this Wall" (Sister Anne). Clemens suffered greatly from the loss of her husband, whom she talks about often when meeting new pilgrims. However, her husband's death became the catalyst to her overcoming the fear to approach the Wall and join the nuns for the prayer of the Rosary. As she explained to me, for nine years now she has been an active member of this weekly prayer.

Another loyal participant in the Rosary is Don Mario, known to the local Christian community as Abuna Mario, an Italian priest who has lived in this area for ten years and describes the Wall thus:

The Wall hides reality; it shatters relationships. I call it diabolical exactly for this reason, because it severs relationships. There was friendship before, among the simple people, between the Palestinian side and the Israeli side, among the Muslims, Jews, and Christians. The Wall broke these relationships. (Abuna Mario) ${ }^{9}$ 
Thus, to him the Rosary is an opportunity to

call upon the Lord because, if horizontally our voice is heard by no one, because this Wall truly breaks everything, they have not yet closed the top, they have not yet built a roof and therefore we believe that by addressing the sky someone will listen to us (Abuna Mario).

Thus, the Rosary is perceived as one of the residual ways in which the voices of the often forgotten Christian population can still be heard. The presence of this cement Wall, in fact, obstructs communication and prevents any interaction between the two sides, thus the Christian plea can only be heard and answered by God. Too often the interviews I conducted recorded the request of my Christian interlocutors to divulge their stories and remind the outside world that among the Palestinians there are Arab Christians as well.

Hence, Sister Anne reveals another important dimension of the recitation of the Rosary, which is the attention it draws among the Christian population and their opposition to the presence of the Wall. She narrates how one evening, as she was approaching Checkpoint 300, a man pulled his car near her and rolled the window down.

He tells me "you are a nun from the Caritas Baby Hospital?" and I answered "yes". "Are you going to recite the Rosary at the Wall?" I replied that I was, but I didn't know this person so I asked him, "Pardon me but who are you?". "We don't know each other, I am a Muslim and I am going to Jerusalem, I found out about this initiative, now I will cross the checkpoint but you should know that I will join you in prayer in this moment, because I know what you are doing for us". Hearing from a Muslim that he knew about our initiative and that he would join us in prayer as a Muslim really moved me. (Sister Anne)

This narration is particularly significant in as much as it reveals the public dimension of the dissent against the Wall specifically enacted by the Christian population. The particular location selected to recite the Rosary not only responds to the necessity of the nuns whose Caritas Baby Hospital is directly affected by the Wall due to its proximity to the checkpoint, but it also represents one of the most significant places where Israeli presence and power is unavoidably deployed. Checkpoint 300, in fact, represents a major access point in the region, so much so that it is referred to as 'the terminal' because its security measures resemble those of an airport terminal. Furthermore, given the constant presence of Israeli military, Palestinian inhabitants, and tourists, the action of these Christians is scrutinised by everyone. Accordingly, we start to gain an understanding of the socio-political implications of the development of a ritual landscape where the Wall so bluntly establishes the border imposed between Israel and Palestine.

\section{OUR LADY OF THE WALL: THE DEVELOPMENT OF A CHRISTIAN SHRINE THAT CONTESTS THE WALL'S BORDERING AGENCY}

When we investigate the impact of the Wall on the lives of the local Arab Christian communities in order to understand what is really at stake underneath the overarching and cloaking narrative of the Wall as a technology of occupation or security, we must embed 
these events within the logic of the Wall as an assemblage. In this case the assemblage embraces an entanglement of the religious practices, rituals, and materialities interacting within a venue that is not considered an official site of the sacred geography of the Holy Land, but which nonetheless is visited by pilgrims and activists and is becoming a potent venue of political dissent over borders. Therefore, scholars such as Stadler and Luz (2015: 127) have analysed the particular venue of Our Lady of the Wall in terms of a new Christian shrine developed as a "political tool by various [human] actors [...] in a dispute over borders". This particular research belongs to a wider branch of studies (Alvarez 1995; Nabhan-Warren 2010; Anzaldúa 2012 [1987]; Hernández and CamposDelgado 2015; Lugo 2015; Napolitano 2015) addressing the "role of sacred places and pilgrimage centers in the context of contemporary geopolitical strife and borders disputes", which understands shrines and sacred sites as "becoming more influential in processes of determining physical borders" (Stadler and Luz 2015: 127).

The relevance of this venue as a Christian border-disputing shrine increased consequently to the presence of the icon of Our Lady of the Wall. As the nuns persisted in their Friday prayer, the importance and visibility of the ritual grew to such an extent that in 2010,

at the request of some nuns living near the Wall, the British iconographer Ian Knowles painted an icon of Mary on the Palestinian side of the barrier. This icon, known as Our Lady of the Wall, is becoming a site of pilgrimage and veneration. (Stadler and Luz 2015: 129)

This icon portrays a pregnant Virgin Mary instead of the most common Mother and Child image.

The peculiarity of the subject chosen for the icon could refer on the one hand to the Book of Revelation (12:1-5) in which

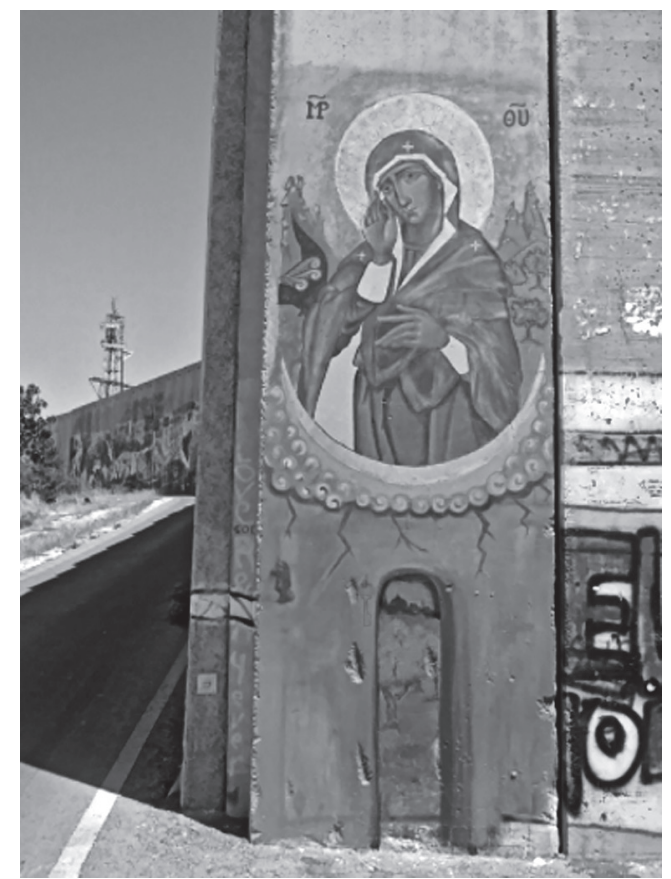

Photo 4. Icon of Our Lady of the Wall painted in 2010 by iconographer Ian Knowles. Photo by the author. "a pregnant woman clothed with the sun and the moon under her feet, and an enormous red dragon with seven heads and ten horns and seven crowns on its heads" is mentioned (Stadler and Luz 2015: 134). This hypothesis can be corroborated by the fact that a large serpentine dragon graffito appeared on the Rosary's Wall route before the Wall was repainted grey for the arrival of Pope Francis in 2014. On the other hand, there could be a connection between the subject of the icon and the increasingly popular images divulged on social media on the interned by activists and supporters of the Palestinian cause. Specifically, one painting, allegedly created by famous British graffiti artist Banksy, portrays a pregnant Mary with Joseph. In this image Mary cannot give birth in Bethlehem because the Wall 


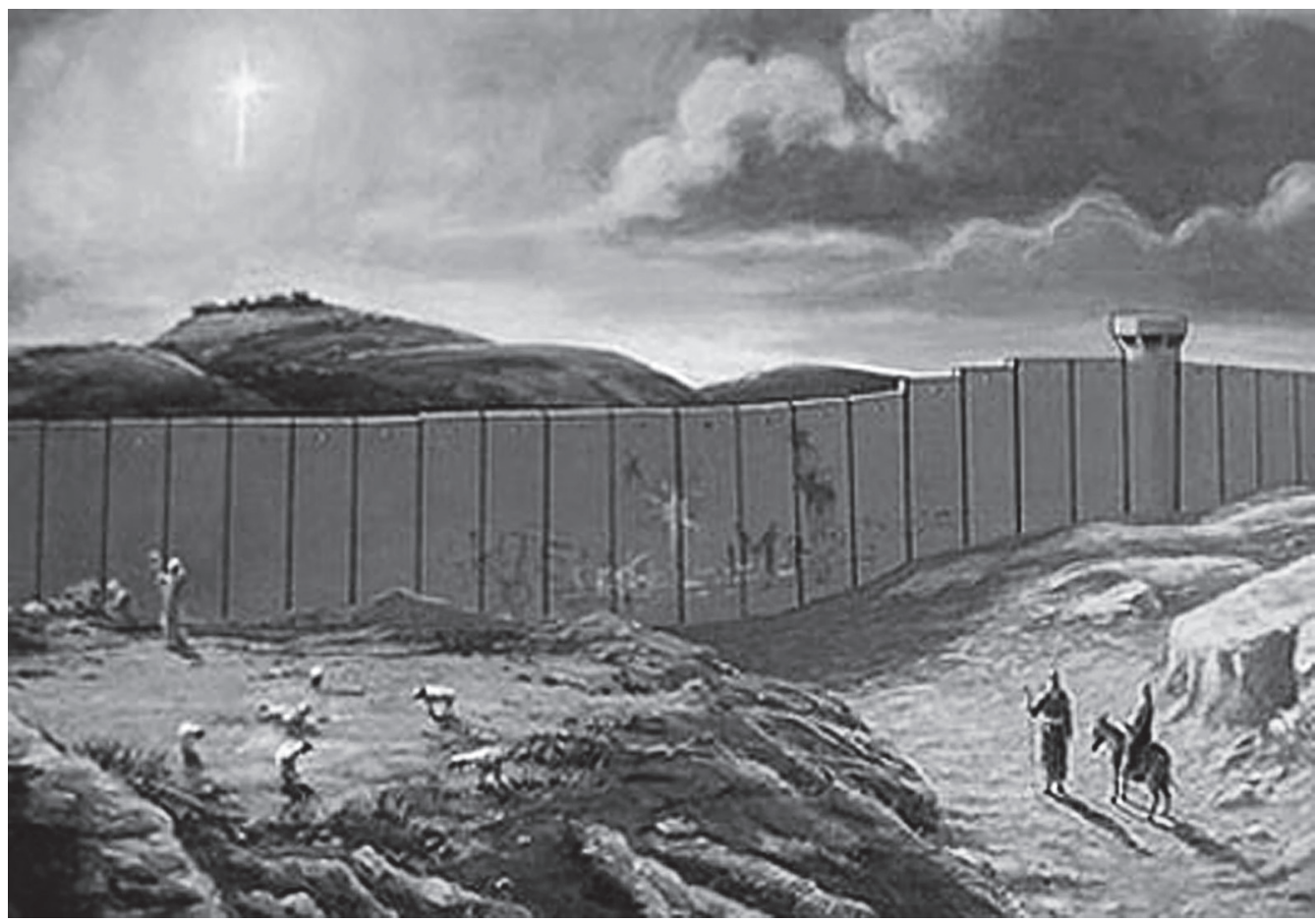

Figure 2. Picture of Mary and Joseph blocked outside Bethlehem by the Wall allegedly painted by graffiti artist Banksy (2015).

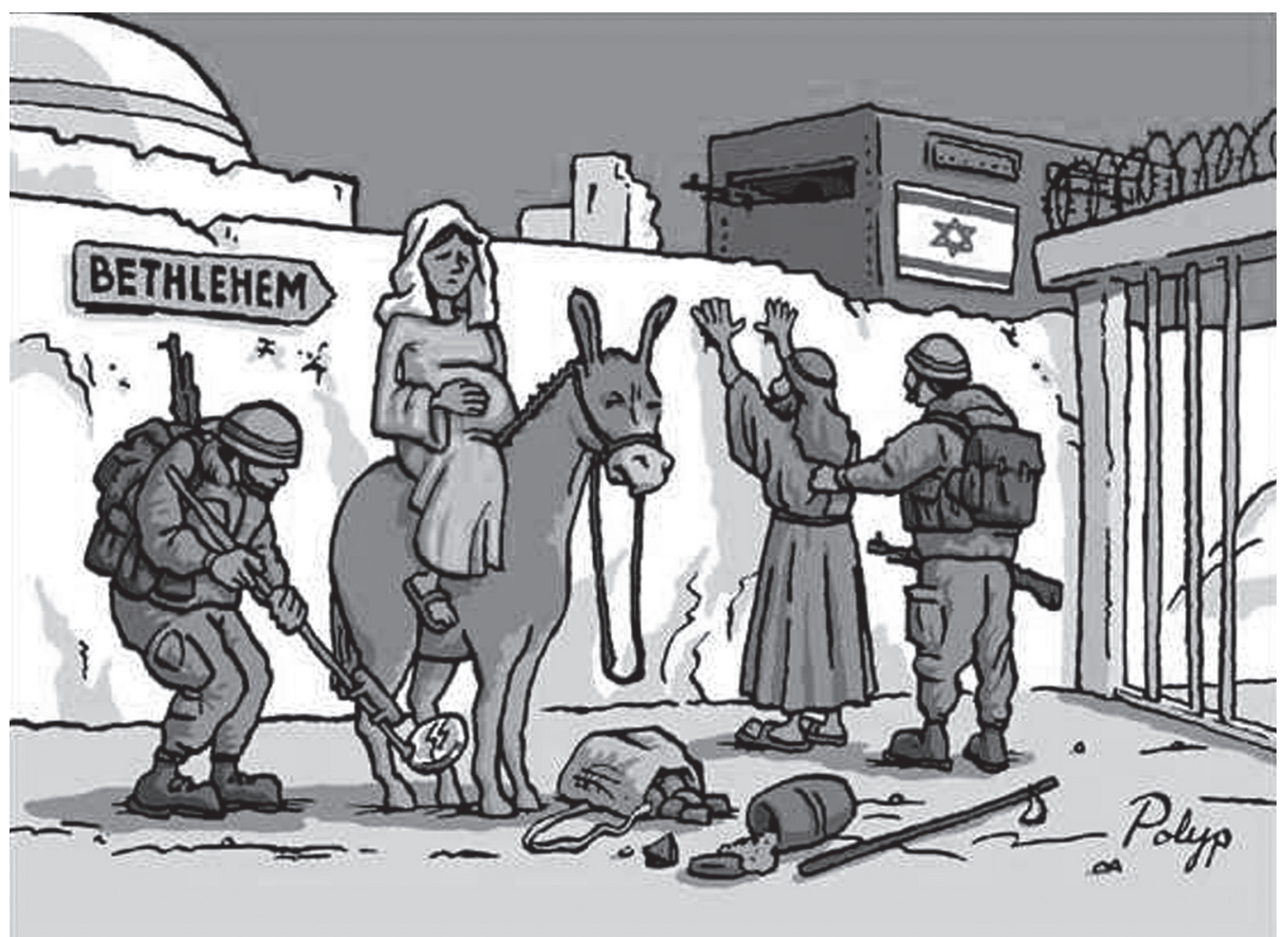

Figure 3. Mary and Joseph inspected at the Checkpoint before entering Bethlehem (Polyp).

JOURNAL OF ETHNOLOGY AND FOLKLORISTICS 11 (1) 
obstructs her and Joseph's way (see Figure 2). Another vignette portrays Mary and Joseph stopped and searched at the checkpoint by Israeli soldiers (see Figure 3). This impediment of movement caused by the Wall and hindering Mary from giving birth to Jesus could refer to the idea that the Wall, in opposition to which Christians pray the Rosary every week, prevents life from flourishing. On this account it is worth mentioning the story of Clemens, whose experience of the Wall connects to her husband's death after losing their lands, or the account of Abuna Mario, who understands the Wall as diabolically preventing any relationships between the people living on opposite sides.

Noteworthy is the decision to paint the icon directly onto the Wall's surface instead of, for example, nailing or cementing a painting to its slabs as has

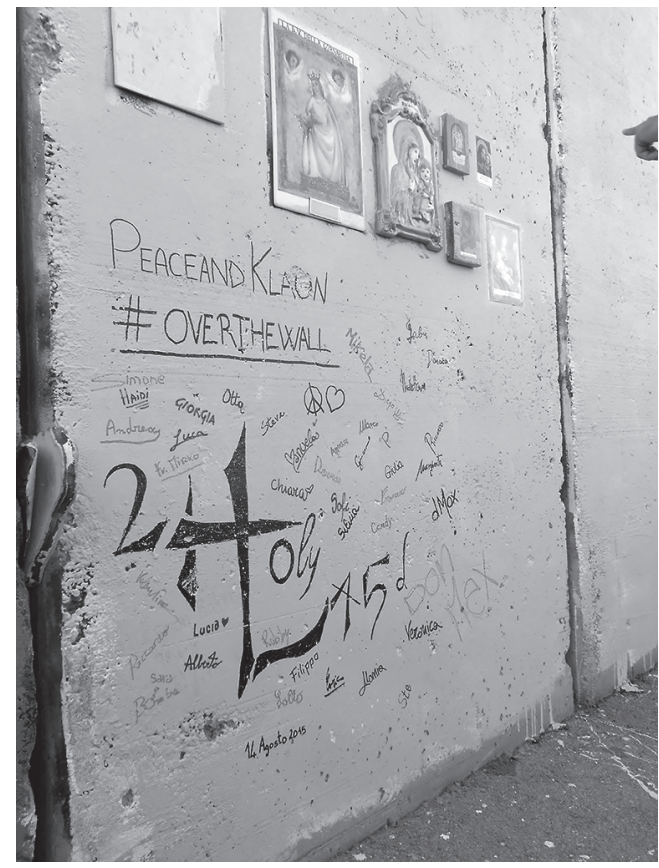

Photo 5. New icons added by Pilgrims next to Our Lady of the Wall. Photo by the author. been done with other icons added at the site by pilgrims (see Photo 5). Thus, the icon fits into a landscape pervaded by graffiti. Both in Israel and Palestine many of the political protests have been made in different historical moments through the use of graffiti. Very common was the usage of graffiti during the first Intifada, as Julie Peteet (1996) describes in her work. Remembered as the "war of stones", in the 1980s and early 1990s in addition to stone throwing, the protest against the Israeli occupation was also voiced through "writing on walls" (ibid.: 139). At the time Peteet wrote her article she was unaware that the "preponderance of stones and stone walls [...] [that] provided ready-made, easily accessible weapons of communication, assault and defense" (ibid.) was going to dramatically increase with the construction of the Wall after the second Intifada. However, despite the fact that two decades have passed, the graffiti are still actors of Palestinian protest, this time against the presence of the Wall that has itself become the cement canvas for their graffiti. For instance, in December 2007 the Bethlehem area and its Wall led Banksy to develop the initiative known as Santa's Ghetto. Along with the London-based organisation Picture on Walls, he relocated "their 'annual squat art concept store' called Santa's Ghetto from London to Bethlehem" (Parry 2010: 9) inviting 14 other international street artists to work side by side with Palestinian artists. ${ }^{10}$ The intent was not merely raising money to be donated to local charities, but to bring foreign visitors to Bethlehem to witness with their own eyes the presence of the Wall. In fact, in order to acquire the works of art produced by the artists on this occasion, the interested buyers had to travel to Bethlehem and bid in person at the auction. The artists located the headquarters for selling their work in a former chicken shop on Manger Square in Bethlehem in front of the Church of the Nativity. Despite the objections of those Palestinians who did not agree with the 
presence of graffiti on the premises because they purportedly embellished and hid the brutality of the Wall, the initiative was very successful and, within a few weeks, Santa's Ghetto raised over one million dollars while also, and most importantly, drawing the world's attention to the social and political implications of the Wall. During my fieldwork in Bethlehem, Banksy's graffiti still constituted an element of pride among the people; they had even become a sightseeing attraction for tourists. However, not all the graffiti are still visible and some of them have been modified by the locals through the years.

This is the milieu in which the icon of Our Lady of the Wall is embedded. Before the arrival of Pope Francis this icon stood at the end of a section of the Wall fully covered in graffiti and shared with them the same 'canvas'. As Peteet (1996: 140) suggested in reference to the first Intifada, the "graffiti did not merely send messages or signify defiance; their mere appearance gave rise to arenas of contest in which they were a vehicle or agent of power". Our Lady of the Wall, in fact, stands as an active non-human agent in the assemblage. Through the faithful weekly prayer of the Rosary, it gains the power to shred the Wall to pieces. Furthermore, like graffiti, the icon reveals the active presence of the Christian minority in the territory and their active participation in the protest against the Wall. It signals a "refusal to acquiesce, a refusal to normalize the abnormal" (ibid.: 155). Hence, just as the first Intifada's graffiti "transformed contested space into a communicative arena" (ibid.: 149), the icon transforms the contested bordering action of the Wall into a Christian ritual landscape aimed at dismantling the Wall.

Moreover, the icon itself communicates the plea of the Palestinian people in general and Christian's in particular. In the icon, in fact, Mary is portrayed with her right hand near her ear. Since the Elizabethan nuns explain that the aim of the Rosary is that of exhorting Mary to grant them the miracle of dismantling the Wall, she has been painted in a listening attitude. Furthermore, underneath the image of Mary, Knowles has painted cracks on the Wall evoking the Virgin's power to smash this Wall to pieces. Moreover, beneath the image of Mary there is an open door depicting the view of Jerusalem with a few olive trees - a symbol of the Palestinian rootedness in the land - that is now concealed by the Wall. Next to the door there is a key which is the symbol adopted by Palestinian refugees to invoke their right of return. There is also a pair of boots, hanging on the Wall, a symbol of those Palestinians who await the chance to walk once again on their land, which the Wall's construction has stolen (Stadler and Luz 2015: 134). We find an important parallel when we consider the icon of Our Lady of the Wall as part of the wider graffiti socio-political and artistic context, i.e. their role as the "voice for those who felt voiceless in the international arena" (Peteet 1996: 145). As hinted above, during the fieldwork, over and over the plea to divulgate the stories of the Christian people emerged from the interviews. My interlocutors often revealed their feeling of being neglected by international attention and aid claiming that all the money was distributed exclusively among the Muslim population. Thus, it becomes evident that the icon of Our Lady of the Wall truly becomes the voice of the forgotten Christians transforming this segment of the Wall into a Christian ritual landscape.

Additionally, the presence of this icon on the Wall is particularly important in as much as Mary in the Christian communities of the Middle East and particularly in Israel and Palestine plays a cardinal role. In fact, as Stadler (2015: 751) tells us, "Mary is being portrayed as the mother of the timid, landless, and oppressed. At times of unrest, 
female themes like fertility and motherhood are increasingly broached within the framework of local politics." Given the status of the Christian population as a religious minority in the West Bank and an ethno-religious minority in Israel, Mary represents the "defender of oppressed minorities in Israel/Palestine, Syria, Jordan, and Egypt" (ibid.: 727). Through the weekly ritual of the recitation of the Rosary, the yearly anniversaries that mourn the construction of the Wall, and the Holy Masses celebrated by pilgrims at the Icon, this venue has become not only a ritual landscape in opposition to the Wall's presence and agency, but it is also becoming recognised as a new Christian shrine. Much as during the first intifada "writing on the walls was a dramatically graphic and visible way of simultaneously responding to and resisting an assignment of public space that attempted to exclude them" (Peteet 1996: 148), it is no coincidence that the recitation of the Rosary has been described by Sister Anne as

our pacific intifada, this is how we have defined it in order to exhort from Mary this miracle: that the Wall might fall, that there could be peace in this land, that these children and families might live in peace and be able to move around as they please.

Our Lady of the Wall, thus, stands as a visible and agentic presence that reclaims a space for the Christians in the face of their increasing departure from the land and their fading into the oversimplifying category of 'Palestinians'. Thus, in the footsteps of Stadler and Luz, through this ethnographic research I unearthed a dimension of the Wall that assembles the security dimension of the controlling and highly militarised Wall with the ritual landscape developed in opposition to its presence. Since the Rosary was developed in confrontation to the construction of the Wall, I demonstrate not only that "ethno-religious struggles over space and resources are altering Jerusalem's sacred landscape" (Stadler 2015: 726), but also that ritual landscapes have become the battlefields of border altercations and venues that channel the attention "upon the oppression and liberation of [...] the nation" (Chidester and Linenthal 1995: 3).

In this dispute over physical borders, the presence of pilgrims is central to contest the presence of the Wall. As discussed below, through their prayers pilgrims impose the right to claim that venue as a Christian site and more broadly to reaffirm the right of existence of the local Christian community and their national objectives of liberation. I concur with David Chidester and Edward Linenthal (1995: 9) when they state that "Although ritual might enact a myth, signal a transition, reinforce political authority, or express emotion, ritualization is perhaps best understood as a particular type of embodied, spatial practice". It is the bodily presence of the believers who participate at the weekly Rosary, their physicality, that stands in those contested spaces, and praying that challenges the "Israel/Palestine's volatile borders and political order" (Stadler 2015: 726). Thus every visitor "use[s] rituals to press for changes to the landscape in the face of ongoing confrontations" (ibid.: 728) "with the objective of calling attention to their plight as ethno-religious minorities in areas and landscapes dominated by Jews and Muslims" (ibid.: 740) characterising this unique ritual landscape as an actual battlefield.

Furthermore, every year on March 1, the local community organises a celebration of the anniversary of the placement of the first cement slab. Thus, pilgrims and activists from various countries participate and through their bodily presence join the dissent 
of local Christians against the construction of the Wall. Moreover, on these occasions unique prayers are devised. For example, on occasion of the 2015 anniversary, the Italian association Un Ponte per Betlemme (which translates into English as a Bridge to Bethlehem) modified Psalm 86 to fit the Palestinian situation and distributed it to all the participants to be recited in front of Our Lady of the Wall. One of the most meaningful and explicative sections of the prayer reads

Listen to the prayer that potently rises from our communities, / on the day in which we remember this odious wall that generates hate / that transforms Bethlehem into a prison. / Help us to transform the generic invocations for peace / into strong words of condemnation and annunciation, / of proximity and indignation, / of faith in you, God who saves and consoles. ${ }^{11}$

These few verses both invoke God's help in tearing down the Wall as well as exhorting all the participants present at the celebration of the anniversary to give voice to the injustice that the Wall brings to the inhabitants of Bethlehem.

In addition to developing a ritual landscape, the agency of the Rosary prayer brings visibility to the presence of Arab Christians and their plight as Palestinians, which the physicality of the Wall conceals. In fact, groups from abroad (predominantly from Italy) are invited to schedule their pilgrimages in such a way as to arrive in Bethlehem on Fridays enabling participation in the recitation of the Rosary. Thus, this site is starting to be included among the pilgrimage venues of the Holy Land that tourists and pilgrims visit during their travels. The narrative that the Elizabethan nuns deliver is that of sharing with the outside world what the pilgrims see in order to communicate the experience of being-in-the-world in a Walled city and the precarious conditions in which the local Christians dwell. There is an attempt to charge the pilgrims with the responsibility of what is happening in Israel and Palestine because

this is the land of the Christians, and not just of the Christians who live here in the Holy Land, so they [pilgrims] must feel this as their own home and ask with one Hail Mary per week that there could be peace here (Sister Anne).

The effervescence that emerges from the development of this initiative, which in turn gives rise to the surge in popularity of a new Christian shrine, springs in response to the presence of the Wall. The more the Wall imposes, the more the world pushes back in the form of complex agency that, as an assemblage of human and non-human actants, disputes its presence and impact on the life of the local population. The Wall itself in its physical presence has become the surface upon which the sacred ${ }^{12}$ has been materially 'posted'. The sacred was even wedged in the crevices of the Wall as the icon of the Virgin Mary of San Luca ${ }^{13}$ has been literally pushed in between the two concrete slabs (see Photo 6). Moreover, Sister Anne cemented two additional icons to the Wall, aiming to increase the agency of Mary against the Wall, as well as expanding the shrine itself, demonstrating how important it is to focus our gaze on the agency of materials. Furthermore, the materiality of the colours used to paint the icon, and the bodily presence of the pilgrims, the sound of the prayers and the singing of the Salve Regina that imbue the landscape, all represent human and non-human actants that surface underneath the overarching and overbearing label of the Wall as a technology of security and occupation. Thus, by looking at the Wall as an assemblage of human and non-human actants 
we uncover the presence of a ritual landscape that, through a decade of unflinching prayer, has been developing into an actual shrine that is increasingly expanding through the posting of new religious icons. When analysing this particular Wall through the assemblage framework, we do not only realise that it cannot be understood as a mere inert cluster of concrete slabs, but also that because of the agency it exercises on the population, a ritual landscape has developed along its route as a battlefield to voice the dissent of a particular religious group: the Christian minority. In turn, the ritual landscape becomes an integral part of the Wall assemblage. We have seen how its formation gathers both human and nonhuman agency, such as Rosary beads, the colours and symbols adopted in the icon of Our Lady of the Wall, the addition of other Marian icons, the physical presence

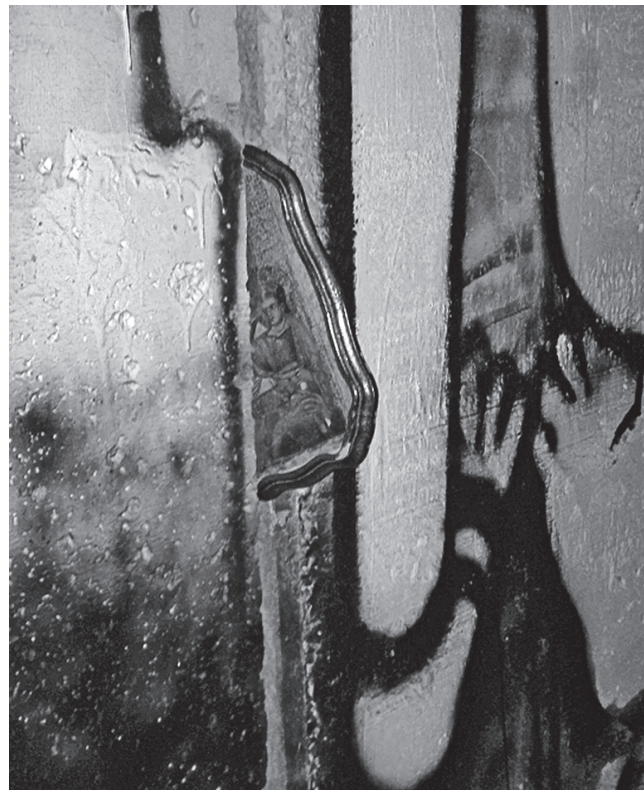

Photo 6. The San Luca Icon pushed in between the Wall's cement slabs near the Icon of Our Lady of the Wall. Photo by the author. in this militarised area of the praying pilgrims, nuns, volunteers, activists, and a few local Christians, the chanting of the Hail Maries, the singing of the Salve Regina, and as discussed in the next section, the Eucharist, the chalice, a portable altar, and the songs and guitars adopted during the celebration of Holy Mass.

\section{TWO HUNDRED PILGRIMS PRAY AT THE ICON OF OUR LADY OF THE WALL}

In the previous section I addressed the agency that the creation of new shrines, or in some cases the revitalisation of ancient ones, exercises in bordering disputes and cultural identity claims (Napolitano et al. 2015). In these disputes, the presence of pilgrims, believers, and activists becomes fundamental to the alleged claims. The bodily presence of the believers who participate in the weekly Rosary, their physicality expressed fully in those contested spaces by praying, reaffirm the right of the Christian minority to exist on that land while, at the same time, contribute to the development of this area as a ritual landscape. In this section I will describe how the presence of two hundred pilgrims from Italy celebrating the Mass at the Our Lady of the Wall icon transformed this ritual landscape into a site of political dissent showing how religious "rituals [allow subjects] to press for changes to the landscape in the face of ongoing confrontations between agents of Judaization, Islamization, and Christianization of Israeli/Palestinian spaces" (Stadler 2015: 728).

On April 10, 2014, a group of 220 pilgrims and local nuns made their way to the checkpoint 300 in order to witness the presence of the Wall and celebrate the Holy Mass 
at Our Lady of the Wall. As I mentioned above, the religious activities that have sprung from the presence of the icon have become, for the pilgrims who visit Palestine, a way to familiarise themselves with the political situation in this land as well as a solicitation for God's intervention to bring peace and justice. On the morning of April 10, the great number of pilgrims aroused suspicion among the Israeli soldiers guarding Checkpoint 300, and they immediately closed the gate. They followed the pilgrims near the icon and asked the priests for explanations. In response the priests replied that they were not doing anything wrong, that they just wanted to pray at Our Lady of the Wall and they would pray for them as well. The soldiers replied that if they wanted to pray, they would have to do so inside the gates of the monastery of the Emmanuel and not by the Wall. The argument lasted sometime, but in the end the priests agreed just to move

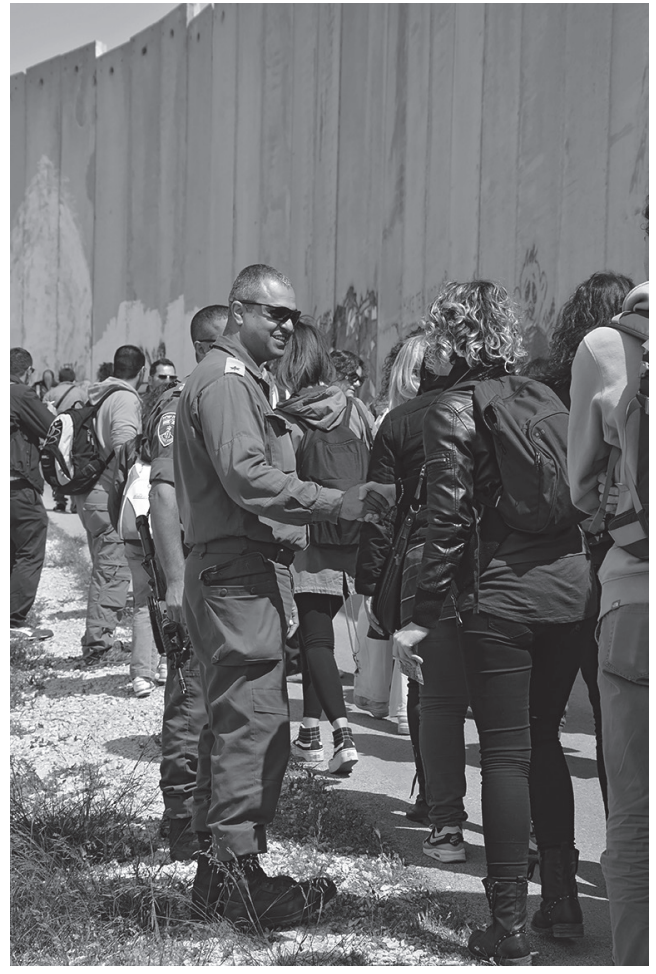

Photo 7. Pilgrims shaking hands with the soldiers monitoring the Holy Mass at Our Lady of the Wall. Photo by the author. one metre away from the Wall refusing to abide by the soldier's request. As the Holy Mass started, more armed soldiers arrived at the site. However, none of them tried to interrupt the prayer. They seemed intrigued by this event and started taking pictures and videos of the Holy Mass. At the conclusion of the celebration all the pilgrims approached the soldiers, shook their hands and hugged them wishing peace upon them ${ }^{14}$ (see Photo 7).

This event further corroborates the influence of pilgrims present at a venue involved in bordering disputes such as Our Lady of the Wall. Analogous to any large gathering happening in the vicinity of the Wall, and because of the pilgrims' intention of celebrating the Mass there, the soldiers perceived the event as a threat to the militarised section of the Wall eliciting the closure of the gate at the checkpoint. However, given the international status of the majority of the pilgrims present, the soldiers could not enforce their request to get away from the Wall and pray within the premises of the Emmanuel monastery. In addition, on this occasion a special prayer was written to invoke the help of Our Lady of the Wall and made into a santino or holy picture. The prayer was recited at the end of the Mass and distributed to all the pilgrims. Thus, the pilgrims, through their prayers, claimed that venue as a Christian site and more broadly reaffirmed the right of existence of the local Christian community and their national objectives of liberation. 
By employing the concept of assemblages proposed by Latour, the Wall ceases to be a mere conglomerate of cement slabs statically set in place to guarantee the security of the Israelis. Instead, within Latour's framework, the Wall triggers the development of a ritual landscape where the weekly prayer of the Rosary is recited to contest the bordering agency of the Wall and to reaffirm the right of the Christian ethno-religious minority to reside on this land. Through the application of an assemblage framework to the ethnographic case study of the weekly Rosary prayer at Our Lady of the Wall, I reveal the formation of this unique ritual landscape that is part of the Wall assemblage and at the same time, developed in contrast to the Wall's presence. The Latourian assemblage framework allows the researcher to unearth the richness of humans and non-humans which, through their agency, gives life to a ritual landscape that interacts and intertwines with the agency that the Wall exercises on the Palestinian population in general and the Christian minority in particular. The variety of actants that partake in the Wall as an assemblage of the ritual landscape of Our Lady of the Wall are the nuns, the volunteers, priests, pilgrims, rosary beads, the first cement slabs, the checkpoint, the watchtower, the machineguns, the Hail Maries uttered to request a miracle, the Salve Regina in Latin. All of these actants become part of an assemblage that connects the Wall's agency as a highly militarised security measure with the humans and nonhumans that partake in the weekly ritual of the Rosary recitation and which are developing a new Christian shrine among its cement slabs.

Through the development of this religion-based initiative, we see how rituals, beliefs, prayers, pilgrims, songs and materials intertwine with the security actants that are at the centre of a dispute over borders and cultural identity. After all, as Chidester and Linenthal (1995: 15) tell us "sacred space is inevitably contested space, a sight of negotiated contests over the legitimate ownership of sacred symbols", and, we might add in our case, the contention over the safeguard of the Arab Christians cultural identity and their narrative. This venue is developing into a ritual landscape that through all its materials and bodily presence of local Christians and pilgrims becomes a battlefield of political dissent against the presence of the Wall and of reaffirmation of the right of the Christian ethno-religious minority to dwell on this land.

Just one question arises from this acknowledgement: what will the future of this venue be if the Wall falls? Will this venue still be a ritual landscape visited by pilgrims and animated by the weekly prayer of the Rosary if the Virgin Mary grants Christians the miracle they beseech?

\section{NOTES}

1 The usage of the term Palestine is very controversial due to the fact that there is no unanimity in regard to its spatial extension, an issue that is reflected in the lack of clear borders of the State of Israel. In fact, the reputed, actual, and desired borders between Israel and Palestine have changed throughout history and varied according to the different actors involved (Halpern 1969; Yehuda 1978; Zureik 2001; Newman 2005; 2006; Marzano and Simoni 2007; Weizman 2007; Shelef 2010; Petti et al. 2011). In this research the term Palestine was used to identify the West Bank, which is not an emic term but is used predominantly by the Western world, including thus also 
the area under full Israeli military control, that is Area C, in as much as my interlocutors think of it as rightfully belonging to the Palestinian people, but under Israeli occupation. Obviously, other interlocutors also identified as Palestine the territory that falls within the ever-shifting borders of the State of Israel.

2 The term to identify this assemblage of human and non-human actants varies greatly depending on the political perspective that activists, politicians and scholars adopt, as well as depending on the architecture adopted in different segments, i.e. in some places it appears under the guise of a complex system of electric fences and barbed wire, in other as an eight-meter-tall concrete wall. Thus, it has been referred to either as Wall, Barrier, or Fence. To know more on this subject, consult Regan Wills 2016.

3 The Bethlehem Governorate consists of 10 municipalities, 3 refugee camps and 58 rural districts. The municipalities included in the Governorate are: Battir, Beit Fajjar, Beit Jala, Beit Sahour, Bethlehem, Al-Dawha, Husan, al-Khader, Nahalin, Tuqu', al-Ubeidiya, and Za'atara.

4 Some of the more relevant and principal cases collected and analysed in my research work are: the development Sumud Story House's project of the "Wall Museum", the Weekly celebration of the Holy Mass among the olive groves of the Cremisan valley as a form of protest against the proposed route of the Wall, the experience of the Franciscan Nuns whose convent in the Aida Refugee Camp area is located in front of the Wall, the case of Claire Anastas and her family whose home is surrounded on three sides by the Wall, the narration of Antoinette whose lands were severed from their home due to the construction of the Wall, etc.

5 When I use the term Christian I refer predominantly to Arab and foreign Roman Catholics (Latin), with a minority of interviews conducted with Melkite Greek Catholic Christians as well as Protestants. Although in Bethlehem, as well as in the West Bank and State of Israel, Roman Catholics do not represent the largest Christian denomination, I have decided to focus primarily on them for several reasons. Firstly, during my past visits to Israel and Palestine I was introduced to various members of this community. Secondly, my status as a member of the Catholic Church allowed me to have a more fluid introduction in the community as well as a direct admittance to the community's activities. Thirdly, and most importantly, it was a group of Catholic nuns and Catholic priests who initiated two of the core activities developed in response to the Wall, which inspired the development of my research. The last reason is tied to linguistic concerns.

6 The Arab Educational Institute (AEI), which is a member of the international peace movement Pax Christi, opened the Sumud Story House in 2009. The Sumud Story House is a building located in the Rachel's Tomb Area where Palestinian women from Bethlehem and the neighbouring towns gather weekly to narrate their experiences living in a walled city. These stories have been written and printed on panels posted on the Wall in the Rachel's Tomb Area constituting the Wall Museum.

7 For instance, at first glance it might be inferred that the farthest away from the Wall Christians live, the least it impacts their lives since they are not involved in the violence and disorders that take place in the Wall's vicinities and they do not have to endure its architectonical impositions daily. However, those Christians living far from the cement slabs still experience its agency that manifests itself under the guise of psychological disorders provoked by the Wall's enactment of closure. An example is represented by the inability to exit freely the West Bank that Lorenzo, an Italian men married to a Palestinian woman who lives in the Bethlehem Governorate, describes:

The family [here] has become what in Arabic we call musas; every family today becomes a soap opera, the musas is a soap opera. The Turkish and South American soap operas here are very popular, and today they have reached every family in Bethlehem, they are the reality in which they live. This happens also because here on Saturdays and Sundays you cannot decide to stop working and go somewhere, get out and visit Jerusalem or go to the seaside or plan a hike in the mountains. You don't even wait for the weekend or for the holydays to 
go out. Here people don't take vacations anymore; there are people here who have three or four years of overdue vacations; where can they go?

8 Original interview with Sister Anne was conducted in Italian.

9 Original interview with Abuna Mario was conducted in Italian.

10 Among them were Souleiman Mansour, Abed al Rohan Mousain, Sam 3, Ron English and Sir Peter Blake. Artists from Ramallah, Gaza and Bethlehem's Dehaisha refugee camp are well represented. Others have come from as far afield as Washington DC, Madrid and East Sussex. (See Banksy 2007)

11 Original text in Italian:

Ascolta la preghiera che si leva potente dale nostre comunità, I nel giorno in cui ricordiamo questo muro odioso e generatore di odio/ che fa di Betlemme una prigione. Aiutaci a trasformare le generiche invocazioni alla pace / in forti parole di denuncia e annuncio, / di prossimità e indignazione, / di affidamento a te, Dio che salca e che consola.

12 Interesting here to think about Emile Durkheim's considerations about the interaction between sacred and profane things. He suggests that the delicate interaction between the sacred and the profane is always a delicate operation that "is impossible if the profane does not lose its specific traits, and if it does not become sacred itself in some measure and in some degree" (Durkheim 1995 [1912]: 38). Following this reasoning thus, the presence of the icon of Our Lady of the Wall, due to its sacred nature, imbues and transforms the Wall and its surroundings into a sacred place.

13 A sanctuary in Bologna, Italy.

14 Ethnographic account published on the website created by the Hebrew University on researches on sacred shrines (see Sacred Sites in Contested Regions).

\section{IN T E R V IEWS}

The names of the interviewees have been changed to guarantee their privacy and safety Abuna Mario, Bologna, Italy, 2012

Mariam, Sumud Story House, Bethlehem, April 2014

Sister Anne, Caritas Baby Hospital, Bethlehem, April 2014

\section{REFERENCES}

Adelman, Jonathan and Agota Kuperman. 2001. The Christian Exodus from the Middle East. - The Foundation for the Defense of Democracies. https://web.archive.org/web/20060524055344/ http://www.defenddemocracy.org/usr_doc/Christian_Exodus_final_2.pdf (accessed May 17, 2017).

Alvarez, Robert R, Jr. 1995. The Mexican-US Border: The Making of an Anthropology of Borderlands. - Annual Review of Anthropology 24: 447-470. DOI: https://doi.org/10.1146/annurev. an.24.100195.002311.

Anzaldúa, Gloria, ed. 2012 [1987]. Borderlands/La Frontera: The New Mestiza. San Francisco, CA: Aunt Lute Books.

ARIJ = The Applied Research Institute - Jerusalem. http://poica.org/upload/Image/rachtomi.jpg (accessed April 26, 2017).

ARIJ 2007 = Geopolitical Status of Bethlehem Governorate. - The Applied Research Institute Jerusalem. http://arij.org/files/admin/2007-2_Geopolitical_Status_of_Bethlehem_Governorate.pdf (accessed March 12, 2017). 
Banksy 2007 = Banksy Moves Santa's Ghetto To The West Bank. http://amandagore.wordpress. com/2007/12/05/banksy-moves-santa's-ghetto-to-the-west-bank/ (accessed March 12, 2017).

Banksy. 2015. Christmas card. https://pbs.twimg.com/media/CW8dUuPWMAETZcD.jpg (accessed March 12, 2017).

Barad, Karen. 2007. Meeting the Universe Halfway: Quantum Physics and the Entanglement of Matter and Meaning. Durham, NC: Duke University Press. DOI: https://doi.org/10.1215/9780822388128.

Barrett, Estelle and Barbara Bolt, eds. 2013. Carnal Knowledge: Towards a 'New Materialism' of the Arts. London: I. B. Tauris.

Bennett, Jane. 2005. The Agency of Assemblages and the North American Blackout. - Public Culture 17 (3): 445-65. DOI: https://doi.org/10.1215/08992363-17-3-445.

Bennett, Jane. 2010. Vibrant Matter: A Political Ecology of Things. Durham, NC: Duke University Press.

Bogost, Ian. 2012. Alien Phenomenology, or What It's Like to Be a Thing. Minneapolis, MN: University of Minnesota Press. DOI: https://doi.org/10.5749/minnesota/9780816678976.001.0001.

Brown, Wendy. 2010. Walled States, Waning Sovereignty. New York, NY: Zone Books.

Bryant, Levi. 2011. The Democracy of Objects. Ann Arbor, MI: Open Humanities Press. DOI: https:// doi.org/10.3998/ohp.9750134.0001.001.

B'Tselem. 2010. 10 years to the second Intifada-summary of data. http://www.btselem.org/press_ releases/20100927 (accessed March 15, 2017).

B'Tselem. 2011. The Separation Barrier. http://www.btselem.org/separation_barrier/map (accessed March 15, 2017).

Chidester, David and Edward T. Linenthal, eds. 1995. American Sacred Space. Bloomington, IN: Indiana University Press.

Connolly, William. 2013. The 'New Materialism' and the Fragility of Things. - Millennium: Journal of International Studies 41 (3): 399-412. DOI: https://doi.org/10.1177/0305829813486849.

Coole, Diana and Samantha Frost, eds. 2010. New Materialisms: Ontology, Agency, and Politics. Durham, NC: Duke University Press.

Csordas, Thomas. 1990. Embodiment as a Paradigm for Anthropology. - Ethos 18: 5-47. DOI: http://dx.doi.org/10.1525/eth.1990.18.1.02a00010.

Csordas, Thomas. 1994a. The Sacred Self: A Cultural Phenomenology of Charismatic Healing. Berkeley, CA; Los Angeles, CA: University of California Press.

Csordas, Thomas, ed. 1994b. Embodiment and Experience. The Existential Ground of Culture and Self. Cambridge: Cambridge University Press.

Csordas, Thomas. 1999. Embodiment and Cultural Phenomenology. - Perspectives on Embodiment: The Intersections of Nature and Culture, edited by Gail Weiss and Honi Fern Haber. New York, NY: Routledge.

Csordas, Thomas. 2011. Embodyment: Agency, Sexual Difference, and Illness. - A Companion to the Anthropology of the Body and Embodiment, edited by Frances E. Mascia-Lees. Malden, MA: Wiley-Balckwell, 137-156. DOI: https://doi.org/10.1002/9781444340488.ch8.

Dolphijn, Rick and Iris van der Tuin. 2012. New Materialism: Interviews and Cartographies. Ann Arbor, MI: Open Humanities Press. DOI: https://doi.org/10.3998/ohp.11515701.0001.001.

Durkheim, Emile. 1995 [1912]. The Elementary Forms of Religious Life. New York, NY: The Free Press.

Farinacci, Elisa and Federica Filippini. 2015. Non di Soli Muri. - Educazione Interculturale 13 (2): 1-28. http://rivistedigitali.erickson.it/educazione-interculturale/archivio/vol-13-n-2/ (accessed March 12, 2017).

Halpern, Ben. 1969. The Idea of the Jewish State. Cambridge, MA: Harvard University Press.

Hannerz, Ulf. 1996. Transnational Connections: Culture, People, Places. New York, NY: Routledge.

Hazard, Sonia. 2013. The Material Turn in the Study of Religion. - Religion and Society: Advances in Research 4: 58-78. DOI: https://doi.org/10.3167/arrs.2013.040104. 
Heidegger, Martin. 1962. Being and Time. New York, NY: Harper and Row.

Hernández, Alberto and Amalia Campos-Delgado. 2015. Saints and Virgins: Religious Pluralism in the City of Tijuana. - Religion and Society: Advances in Research (Special Issue: Borderlands and Religion) 6: 142-154.

Hurd, Ian. 2008. Constructivism. - The Oxford Handbook of International Relations, edited by Christian Reus-Smith and Duncan Snidal. Oxford: Oxford University Press.

Latour, Bruno. 1999. Pandora's Hope: Essays on the Reality of Science Studies. Cambridge, MA: Harvard University Press.

Latour, Bruno. 2004. Politics of Nature: How to Bring the Sciences into Democracy. Cambridge, MA: Harvard University Press.

Latour, Bruno. 2005. Reassembling the Social: An Introduction to Actor-Network-Theory. New York, NY: Oxford University Press.

Lugo, Alejandro. 2015. Occupation, Religion, and the Voidable Politics of Empire at the US-Mexico Border. - Religion and Society: Advances in Research (Special Issue: Borderlands and Religion) 6: 99-126.

Marzano, Arturo and Marcella Simoni, eds. 2007. Quaranta Anni Dopo. Confini, Barriere e Limiti in Israele e Palastina (1967-2007). Bologna: Il Ponte.

Merleau-Ponty, Maurice. 1962. The Phenomenology of Perception. London: Routledge.

Merleau-Ponty, Maurice. 1968. The Visible and the Invisible. Evanston, IL: Northwestern University Press.

Miller, Daniel. 2010. Stuff. Cambridge: Polity Press.

Morton, Timothy. 2013. Hyperobjects: Philosophy and Ecology after the End of the World. Minneapolis, MN: University of Minnesota Press.

Nabhan-Warren, Kristy. 2010. Borderlands. - The Blackwell Companion to Religion in America, edited by Philip Goff. Oxford: Wiley-Blackwell, 29-41. DOI: https://doi.org/10.1002/9781444324082. ch3.

Napolitano, Valentina; Nimrod Luz and Nurit Stadler. 2015. Materialities, Histories, and the Spatialization of State Sovereignty. - Religion and Society: Advances in Research (Special Issue: Borderlands and Religion) 6: 90-97.

Newman, David. 2005. From Hitnachlut to Hitnatkut: The Impact of Gush Emunim and the Settlement Movement on Israeli Politics and Society. - Israel Studies 10 (3): 192-224. DOI: https:// doi.org/10.2979/ISR.2005.10.3.192.

Newman, David. 2006. Shared Spaces - Separate Spaces: The Israel-Palestine Peace Process. GeoJournal 29 (4): 363-375.

OCHA. 2012. West Bank Movement and Access Update. https://www.ochaopt.org/documents/ ocha_opt_movement_and_access_report_september_2012_english.pdf (accessed March 15, 2017).

OCHA. 2015. Bethlehem Governorate: Fragmentation and Humanitarian Concerns. https://www. ochaopt.org/content/bethlehem-governorate-fragmentation-and-humanitarian-concerns-january-2015 (accessed March 26, 2017).

Parry, William. 2010. Against the Wall. The Art of Resistance in Palestine. London: Pluto Press.

Peteet, Julie. 1996. The Writing on Walls: The Graffiti of the Intifada. - Cultural Anthropology 2: 139-159. DOI: https://doi.org/10.1525/can.1996.11.2.02a00010.

Petti, Alessandro; Nicola Perugini, Sandi Hilal and Eyal Weizman. 2011. Linea Verde Il Limes Senza Legge. - Limes 3: 123-128.

Polyp. Website for Polyp the cartoonist. http://www.polyp.org.uk/cartoons/arms/polyp_cartoon_ israel_palestine_gaza_bethlehem_wall.jpg (accessed May 4, 2017).

Regan Wills, Emily. 2016. Constructing a "Wall": Discursive Fields, Social Movements, and the Politics of the [Wall/Barrier/Fence]. - Journal of Borderlands Studies 31 (3): 305-318. DOI: https://doi.org/10.1080/08865655.2016.1174596. 
Sacred Sites in Contested Regions. http://sacredplaces.huji.ac.il/sites/our-lady-wall (accessed March 12, 2017).

Shelef, Nadav G. 2010. Evolving Nationalism: Homeland, Identity, and Religion in Israel, 1925-2005. Ithaca, NY: Cornell University Press.

Stadler, Nurit. 2015. Appropriating Jerusalem through Sacred Places: Disputed Land and Female Rituals at the Tombs of Mary and Rachel. - Anthropological Quarterly 88 (3): 725-758. DOI: https://doi.org/10.1353/anq.2015.0030.

Stadler, Nurit and Nimrod Luz. 2015. Two Venerated Mothers Separated by a Wall. Iconic Spaces, Territoriality, and Borders in Israel. - Religion and Society: Advanced Research (Special Issue: Borderlands and Religion) 6: 127-141.

The World Factbook: West Bank. https:/www.cia.gov/library/publications/the-world-factbook/ geos/we.html (accessed May 17, 2017).

Weizman, Eyal. 2007. Hollow Land: Israel's Architecture of Occupation. London: Verso.

Yehudah, Elizur. 1978. The Borders of Eretz Israel in Jewish Tradition. - Whose Homeland: Eretz Israel Roots of the Jewish Claim. Jerusalem: Achva Press, 42-53.

Zureik, Elia. 2001. Constructing Palestine through Surveillance Practices. - British Journal of Middle Eastern Studies 28 (2): 205-227. DOI: https://doi.org/10.1080/13530190120083086. 